\title{
Adaptation of 'Early Climate Change Disaster' to the Northern Coast of Java Island Indonesia
}

\author{
Heri Andreas ${ }^{a,}$, , Hasanuddin Z. Abidin ${ }^{\mathrm{b}}$, Dina A. Sarsito, and Dhota Pradipta \\ Geodesy Research Division Institute of Technology Bandung, Indonesia \\ E-mail: aheriandreas49@gmail.com (Corresponding author), bhzabidin@gmail.com
}

\begin{abstract}
In the last few decades, the tidal inundation and abrasion along northern coast of Java Indonesia have been grown very rapidly. These situations are far beyond the geological scale. These are way too fast. Time series of high resolution satellite image data shows very clearly the tidal inundation and abrasion existence. In the recent years in fact the tidal inundation is obviously going further deeper inland. Many of urban and other areas like farming area, fishpond, etc. have been suffered tidal inundation and becoming worse in times. First it was only few centimetres of inundation and come only at a high tide, but now it can be more than a half of meter and coming at regular tide, and even has comes permanently in certain places. Many of the area along northern coast of Java are also suffering abrasion due to frequently of bad weather with storm surge strike the coastal area. What is happening to the northern coast of Java Island Indonesia is one most clear pictures of 'early climate change disaster'.

Adaptation has been created against this 'early climate change disaster' such as build dykes, elevate the land, houses, infrastructures, etc. This paper will tell in details and comprehensively regarding adaptation of 'early climate change disaster' to the northern coast of Java Island Indonesia. This is one way to remain on what would happen in the future world wide as the global climate change consequences are finally coming. We have seen the news of the projection model of sinking of coastal cities in the world, vanishing Islands around the Pacific, etc. in the future.
\end{abstract}

Keywords: Global climate change, disaster, early pictures, adaptation.

ENGINEERING JOURNAL Volume 22 Issue 3

Received 12 January 2018

Accepted 13 February 2018

Published 28 June 2018

Online at http://www.engj.org/

DOI:10.4186/ej.2018.22.3.207

This article is based on the presentation at The International Symposium of the $11^{\text {th }}$ SSMS and the $5^{\text {th }}$ RCND 2017 in Bangkok, Thailand, $20^{\text {th }}-21^{\text {st }}$ September 2017. 


\section{Introduction}

Humans have caused major global climate changes today. Most climate scientists agree the main cause of the global climate changes is further effect of current global warming trend by human expansion of the "greenhouse effect". Certain gases like CO2 in the atmosphere block heat from escaping. Long-lived gases that remain semi-permanently in the atmosphere and do not respond physically or chemically to changes in temperature are described as "forcing" climate change. $\mathrm{CO}_{2}$ (Carbon dioxide) is a minor but very important component of the atmosphere. $\mathrm{CO} 2$ is released through natural processes such as respiration and volcano eruptions and through human activities such as deforestation, land use changes, and burning fossil fuels. Humans have increased atmospheric $\mathrm{CO}_{2}$ concentration by more than a third since the Industrial Revolution began. This is the most important long-lived "forcing" of global climate change. This global climate change situation due to global warming has been realized for the few decades. Some indicators are worldwide increasing temperature, decreasing volume of ice in Antarctica, the sea level rise, and not to mention the severe storm surge and any of bad weathers anomaly. The increasing temperature of the earth has been brought ice to melt in Antarctica and made volume of water larger. As the consequences the sea level rise exists.

Figure 1 show graph of sea level rise that is happening in the ocean worldwide from recorded of tide gauges (1970-2005) and Satellite Altimetry data (1992-2010) reported by IPCC. Generally the sea level rise is ranging in order millimetre to few centimetres per year. Only few places in the world are experiencing in larger magnitude, but it is not more than a few decimetres per year. This sea level rise even in the small magnitude in theory can also influence the tidal inundation respectively. The sea level rise it shelf according to IPCC as previously mentioned is due to global climate change. The increasing temperature of the earth has been brought ice to melt in the north and south Antarctica and made volume of water larger. As the consequences the sea level rise exists. The sea in Indonesia is experiencing sea level rise in order of few millimetres per year (Nurmaulia et al. 2010)

Satellite altimetry is satellite base geodetic technique that has good capability in sensing sea level rise from the satellite. By using electromagnetic pulse we can measure the range from sea surface (footprint) to the satellite with accuracy in order of few centimetres. The satellite is equipped with the GPS (Global Positioning System) that can provide height of either satellite or sea surface above ellipsoid reference system.

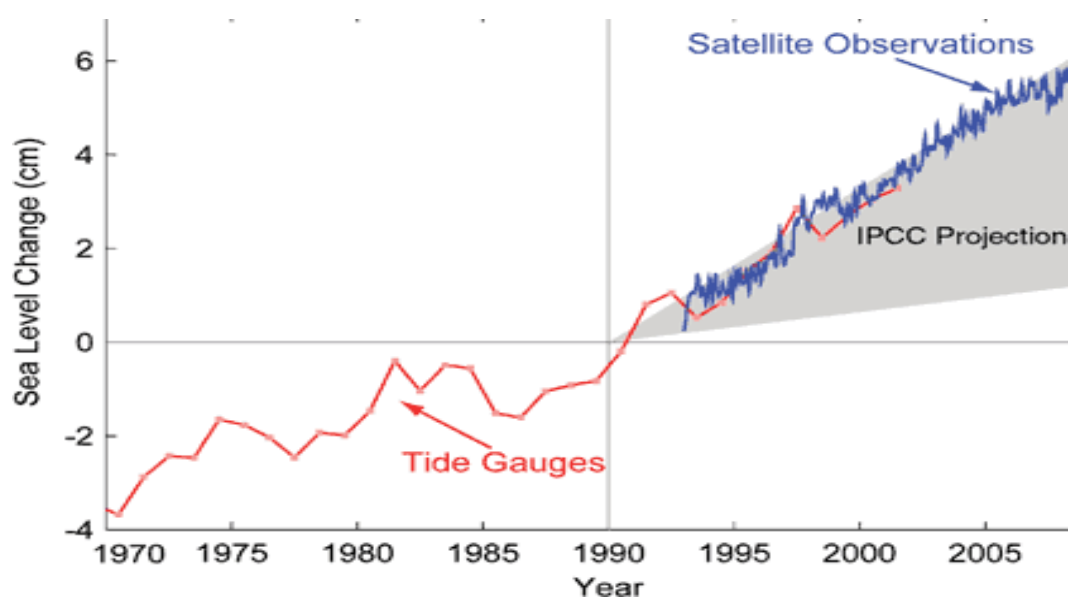

Fig. 1. Recorded of tide gauges (1970-2005) and Satellite Altimetry data (1992-2010) indicating sea level rise (in centimetre scale) as the consequences of global clime change (Modified from IPCC graph).

Relating to the decreased of ice volume and the sea level rise, this situation has been predicted to endanger the living at the coastal area in the future. Prediction models have shown some coastal cities area would suffer flood by tidal inundation and even permanent flooding (Fig. 2). The tidal inundation in certain form may lead to serious ecological disaster. People may suffered from the inundation (e.g. health, economic, and even social), and some probably even have to evacuate from their homeland. Environments are degrading in their quality as well. It will be a disaster. 

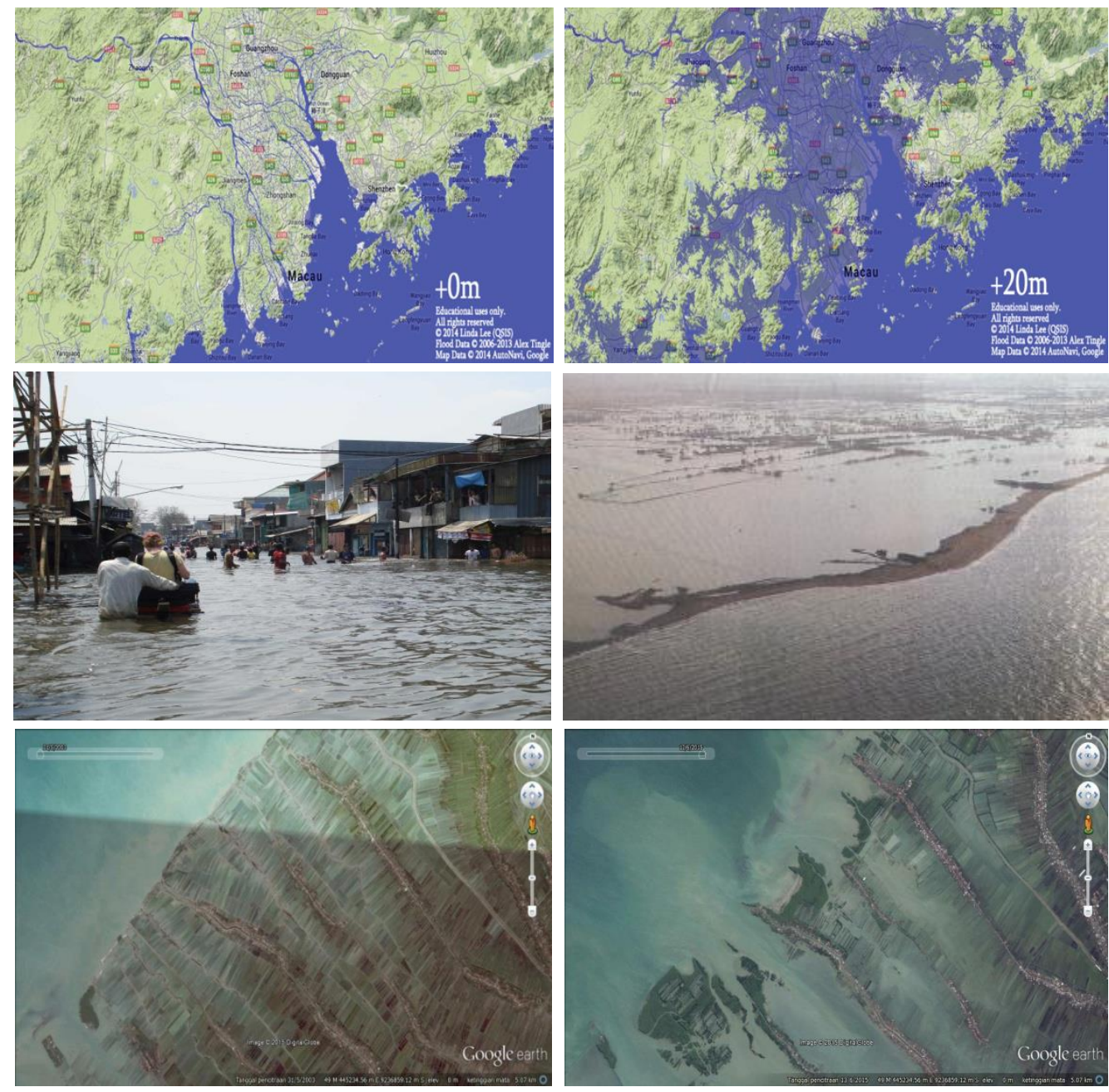

Fig. 2. Model simulation of sea inundation (dark blue on the figures first row) as the sea level is rising up to 20 meter from scenario of global climate change consequences in Macau area (modified from Linda lee QSIS). Second row shows field documentation of sea inundation, while third row shows Google time series satellite image picturing the growth of sea inundation took place around northern coast of Java Island.

Severe storm surge and any of bad weathers anomalies come more frequently on the last decade due to another consequence of global climate change. When they strike the coastal area, potential abrasion increased and in certain time formed disaster to the area. If we take a look surrounding coastal area northern of Java Island Indonesia, we have witnesses housing and infrastructures were damage by the abrasion. Time series of satellite image data shows clear abrasion area. The tidal inundation is also clearly shown in many places along northern of Java Island from time series of satellite data. Seems we have an obvious of 'early climate change disaster' from this area. The inundation and abrasion have been effected the health, economy, and social. People in some villages around coastal area have to elevate their houses regularly and even some have to abandon their houses due to permanent inundation. People are literally suffering from the inundation and environments are degrading in their quality as well.

Adaptation has been created against this 'early climate change disaster' such as build dykes, elevate the land, houses, infrastructures, etc. This paper will tell in details and comprehensively regarding adaptation of 'early climate change disaster' to the northern coast of Java Island Indonesia including their effectiveness. This is one way to remain on what would happen in the future world wide as the global climate change consequences are finally coming. We realize by the news the projection model of sinking coastal cities in the world, vanishing Islands around the Pacific, etc. in the future. 


\section{Insight 'Early Pictures of Climate Change Disaster'}

Java Island is one of the biggest islands and the densest population in Indonesia (Fig. 3). The straight length of the Island approximately reached 1000 kilometre. The northern part of the island (e.g. the coastal area) is one of the strategic places for our national development. Many of urban area including big cities like Jakarta, Bekasi, Cirebon, Pekalongan, Semarang, and Surabaya lies along this area. More than 50 percent of people in Java island living in those cities. Within the urban areas along the northern coast of Java, many of industrial area and trading area are being established. Others shape like farming area, fishpond, etc lies also along the area. In the last few decades, the tidal inundation and abrasion along northern part of Java have been grown very rapidly. These situations are far beyond the geological scale. Time series of high resolution satellite image data shows very clearly the tidal inundation and abrasion (Fig. 4). In the recent years in fact the tidal inundation it is obviously going further deeper inland. Many of urban and other areas like farming area, fishpond, etc. have been suffered tidal inundation and becoming worse in times. First it was only few centimetres of inundation and come only at a high tide, but now it can be more than a half of meter and coming at regular tide, and even has comes permanently in certain places (Fig. 5).

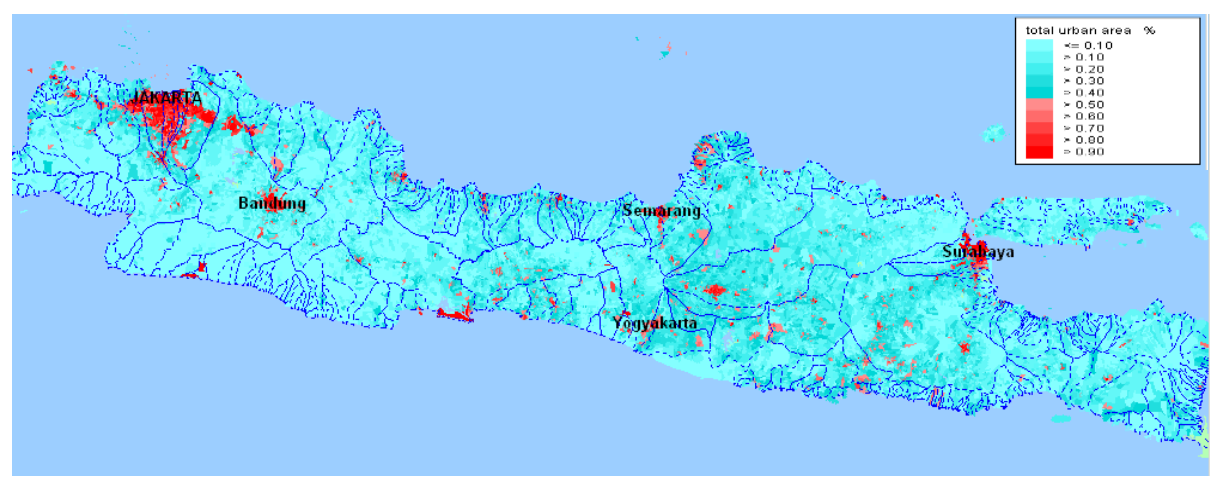

Fig. 3. Java Island and the northern coast of the Island (courtesy of Deltares) where many of urban area including big cities like Jakarta, Bekasi, Cirebon, Pekalongan, Semarang, and Surabaya lies along this area.
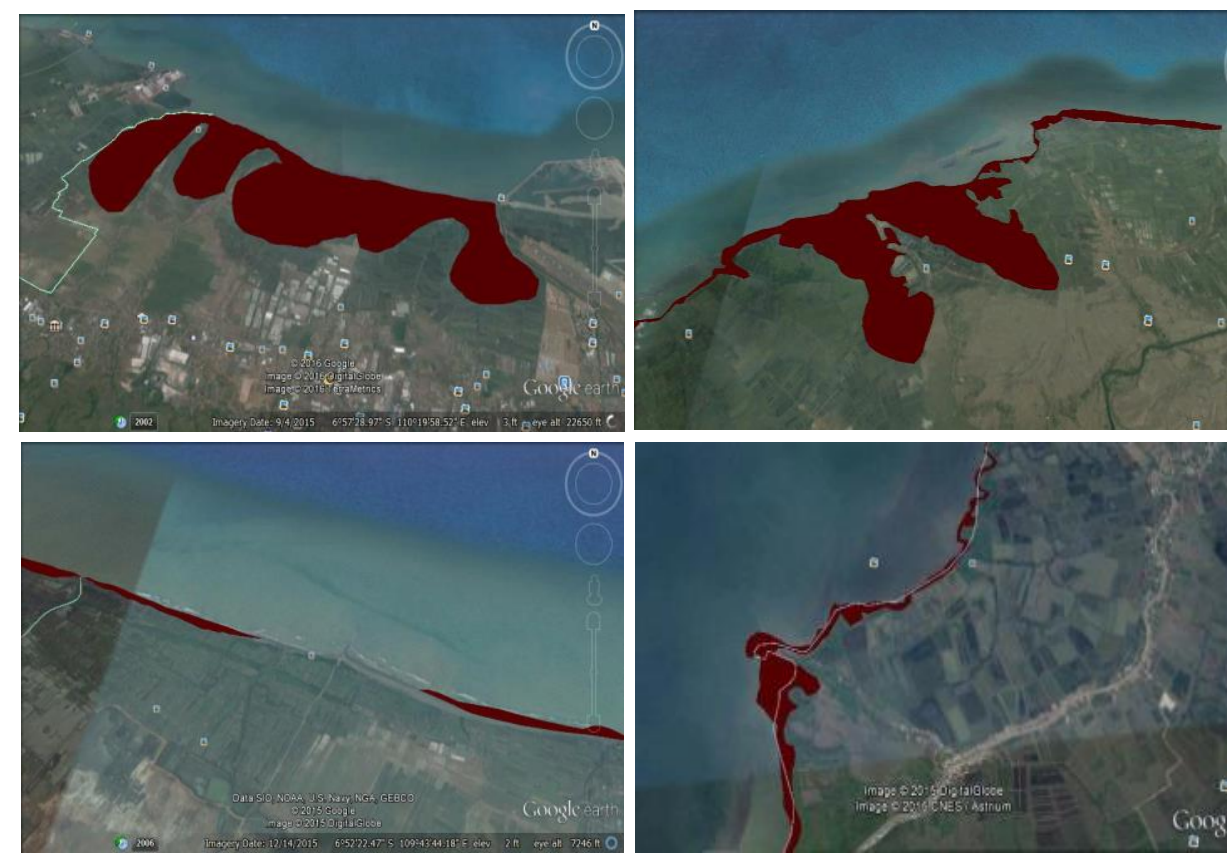

Fig. 4. Example of delineation polygon area represented tidal inundation and abrasion areas taken from the old and the new coast line along northern coast of Java. 

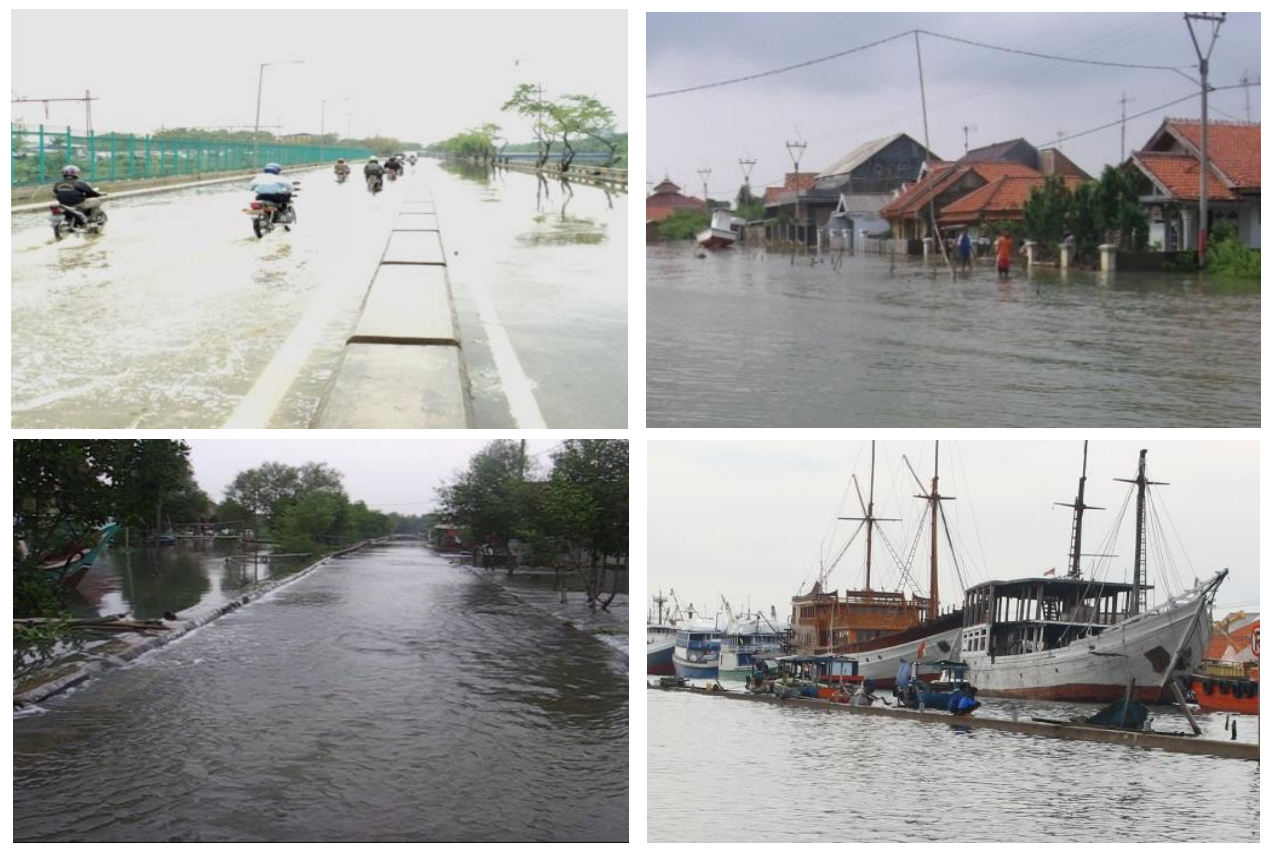

Fig. 5. The figures are site documentations of tidal inundation in Jakarta city, Pondok Bali, and Semarang area. More places along northern part of Java are also suffering this tidal inundation in the recent years and probably worsening in the future.

Based on our investigation, we can see the tidal inundation and abrasion are taking place at least in Tanggerang, Jakarta, Bekasi, Pondok Bali, Blanakan, Indramayu, Cirebon, Brebes, Tegal, Pemalang, Pekalongan, Batang, Kendal, Semarang, Demak, Gresik, Surabaya, and Sidoarjo, and perhap we would found many others unmeasured area being inundated especially the temporary one. In Tanggerang at least 94.6 hectares are suffering inundation. In Jakarta at least 7.2 hectares are suffering inundation. In Bekasi at least 279.0 hectares are suffering inundation. In Karawang at least 82.0 hectares are suffering inundation. In Subang (Pondok Bali and Blanakan) at least 943.0 hectares are suffering inundation. In Indramayu at least 261.0 hectares are suffering inundation. In Cirebon at least 99.0 hectares are suffering inundation. In Pemalang and Pekalongan at least 21.0 and 13.8 hectares are suffering inundation. In Semarang at least 1157.8 hectares are suffering inundation. In Demak at least 3221.0 hectares are suffering inundation. Table 1 shows complete summary location and each total area being inundated along northern coast of Java. We can see that Demak area is suffering the largest tidal inundation followed by Semarang.

We delineate and calculate the area being suffering abrasion from the polygon integrated together with publication data by Budianto, 2012; Pribadi \& Helmi, 2012. In Bekasi at least 109.3 hectares are suffering abrasion. In Karawang at least 79.9 hectares are suffering abrasion. In Indramayu at least 478.3 hectares are suffering abrasion. In Cirebon at least 384.0 hectares are suffering abrasion. In Brebes 2115.3 hectares are suffering abrasion. In Tegal at least 58.6 hectares are suffering abrasion. In Pemalang and Pekalongan at least 231.0 and 77.3 hectares are suffering abrasion. In Kendal at least 317.4 hectares are suffering abrasion. In Semarang at least 342.6 hectares are suffering abrasion. In Jepara at least 938.7 hectares are suffering abrasion. In Rembang at least 852.8 hectares are suffering abrasion, and in Gresik at least 100.0 hectares are suffering abrasion. A complete summary location and each total area being suffered abrasion along northern coast of Java is shown on Table 1. We can see that Brebes area is suffering the largest abrasion followed by Jepara.

Name of village that are suffering tidal inundation is given on Table 2. According to some people in the villages, the tidal inundation started to intrude their land around early in 2000. First it was only few centimetres of inundation and come only at a high tide, but now it can be more than a half of meter and coming in regular tide, and even has comes permanently in certain places for the recent years. Figure 6 shows map and figures that sumarize us spatialy of tidal inundation and abrasion in many locations along nortern coast of Java as result of our investigation. 

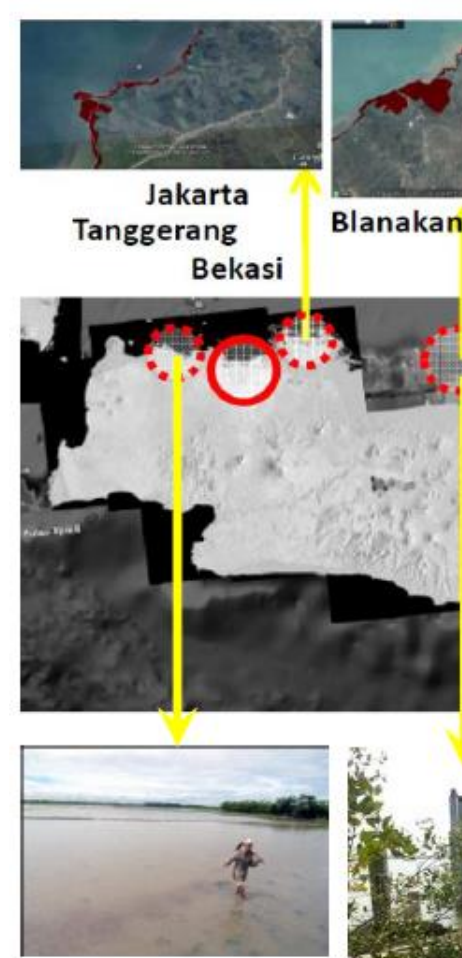

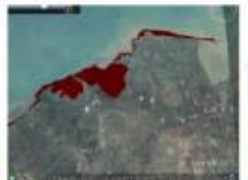

Brebes

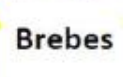

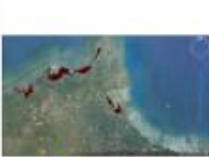

Pekalongan Pemalang

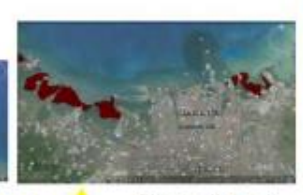

Semarang

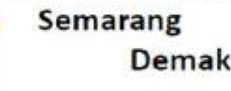

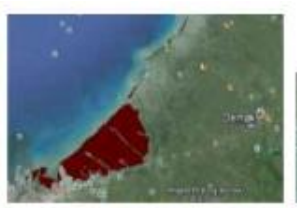

Gresik

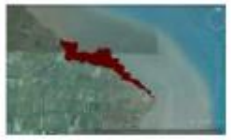

Surabaya
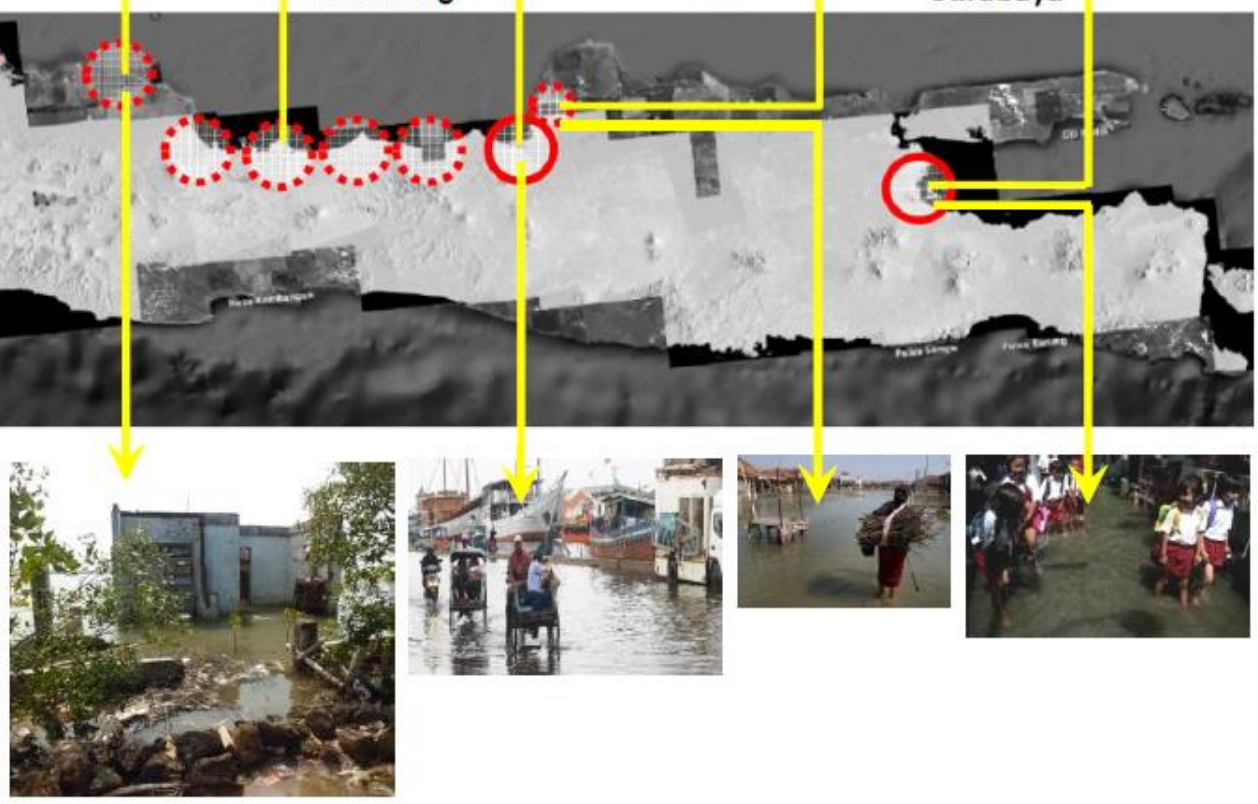

Fig. 6. Tidal inundation and abrasion in many locations along northern coast of Java from all high resolution satellite images data and others supported data being collected and analized.

Table 1. Summary location and each total area being inundated and suffering abrasion in northern coast of Java, from time series of satellite image analysis from 2000 to recent years and others supported secondary data available.

\begin{tabular}{llrr}
\hline Location & Province & Tidal Inundation & Abrasion \\
\hline 1. Tanggerang & West Java & & - hectare \\
2. Jakarta & Jakarta & 94.6 hectare & - hectare \\
3. Bekasi & West Java & 7.2 hectare & 109.3 hectare \\
4. Karawang & West Java & 279.0 hectare & 79.9 hectare \\
5. Subang & West Java & 94.0 hectare & - hectare \\
6. Indramayu & West Java & 261.0 hectare & 478.3 hectare \\
7. Cirebon & West Java & 99.0 hectare & 384.0 hectare \\
8. Brebes & Central Java & 299.0 hectare & 2115.3 hectare \\
9. Pemalang & Central Java & 21.0 hectare & 231.0 hectare \\
10.Pekalongan & Central Java & 13.8 hectare & 77.3 hectare \\
11.Batang & Central Java & 11.0 hectare & - hectare \\
12 Kendal & Central Java & 258.9 hectare & 317.4 hectare \\
13.Semarang & Central Java & 1157.8 hectare & 342.6 hectare \\
14.Demak & Central Java & 3221.0 hectare & - hectare \\
15.Jepara & Central Java & 97.0 hectare & 938.7 hectare \\
16.Gresik & East Java & 151.0 hectare & 100.0 hectare
\end{tabular}

Source : Primary data processing from satellite images and secondary data processing (modified from Budianto, 2012; Pribadi \& Helmi, 2012). 
Table 2. Summary of the districts or villages being inundated from insitu measurements and news informations in the recent years along northern coast of Java.

\begin{tabular}{|c|c|c|}
\hline Location & Province & $\begin{array}{l}\text { District or Villages being suffering tidal } \\
\text { inundation base on integration of news internet } \\
\text { and insitu measurements }\end{array}$ \\
\hline 1. Tanggerang & Banten & Kosambi, Dadap \\
\hline 2. Jakarta & Jakarta & $\begin{array}{l}\text { Muara baru, Sunter agung, Pademangan barat, } \\
\text { Muara Angke, Cilincing }\end{array}$ \\
\hline 3. Bekasi & West Java & $\begin{array}{l}\text { Hurip jaya, Donggala, Muara angke, Pantai } \\
\text { mekar }\end{array}$ \\
\hline 4. Subang & West Java & $\begin{array}{l}\text { Desa Mayangan, Desa Legon wetan, Desa } \\
\text { Legon kulon }\end{array}$ \\
\hline 5. Indramayu and Cirebon & West Java & Desa Eretan, Kelurahan Lemahwungkuk \\
\hline 6. Tegal & Central Java & $\begin{array}{l}\text { Desa Tegal sari dan Desa Muarareja, Desa } \\
\text { Mintaragen dan Desa Panggung }\end{array}$ \\
\hline 7. Pemalang & Central Java & $\begin{array}{l}\text { Desa Pedangung, Desa Sususkan, Desa } \\
\text { Kebojongan dan Desa Klegen, Desa Jatirejo, } \\
\text { Desa Sidokare, Desa Ujung gede dan Desa } \\
\text { Losari, Desa Kendal doyong, Desa Kendal rejo, } \\
\text { Desa Tebuireng, Desa Widodaren, Desa } \\
\text { Pasucen, Desa Panjunan, Desa Sirangkang, Desa } \\
\text { Limbangan mojo, Desa Tasik rejo dan Desa } \\
\text { Pesantren, Desa Pendowo dan Desa Kelang } \\
\text { depok }\end{array}$ \\
\hline 8. Semarang and Demak & Central Java & $\begin{array}{l}\text { Marina, Tanjung Mas, Kaligawe, Terboyo, Desa } \\
\text { Sriwulan, Desa Bendono, Desa Purwasari, Desa } \\
\text { Sidogemah, Desa Gemulak, Desa Tugu, Desa } \\
\text { Timbulsloko, Desa Suradadi, Desa Sidorejo, dan } \\
\text { Desa Banjarsari }\end{array}$ \\
\hline 9. Gresik and Surabaya & East Java & $\begin{array}{l}\text { Kelurahan Lumpur, Desa Kalianak, Desa } \\
\text { Margomulyo, dan Desa Greges }\end{array}$ \\
\hline
\end{tabular}

The inundation has been effected the health, economy, and social. People in some villages in Pondok Bali, Semarang, and Demak have to abandon their houses due to permanent inundation. People are suffering from the inundation and the environments are degrading in their quality as well. Base on the interview it concluded that most of the people in the villages do not understand the causes of tidal inundation, and even what would happen in the future. We absolutely need mitigation or adaptation against this 'early climate change disaster'.

\section{Adaptation of 'Early Climate Change Disaster'}

Adaptation has been created against this 'early climate change disaster' such as build dykes, elevate the land, infrastructures, etc. The adaptation can be categorizing as short term measures and long term measures. Remember also the adaptation from climate change is not only from tidal inundation and abrasion but also from drought, risk on food securities, etc. Nevertheless the clear pictures of climate change impact's today are tidal inundation and grown abrasion. As for mitigation, we have seen it is still beyond the agenda. Neither it is hardly to stop the complexity of combination of global warming effect and others factor to the climate change nor did we never find way to mitigate. Maybe reducing sources of CO2 (for example, the burning of fossil fuels for electricity, heat or transport) or enhancing the "sinks" that accumulate and store CO2 and others gases (such as the oceans, forests and soil) are not easy so far.

One or even two meter of dyke already can be seen in several places along the coastal area northern of Java such as in Jakarta, Pondok Bali, Pekalongan, Semarang, and Demak area. The constructions mostly use the sheet pile. As quick response people indeed put the sand bag along the coastal and river banks (Fig. 7). A 
huge plan on establishing permanent dyke is prepared in Jakarta and Semarang city. There will be "Giant Sea Wall" closing Jakarta Bay, and Toll Dykes along shoreline of Semarang in the near future. There will be another plan for Pekalongan and Blanakan area. The length of the dyke is about 60 kilometres for Jakarta and 20 kilometres for Semarang. The huge flooding from the sea was strike Jakarta in year 2007 and in about the same time it was also strike Semarang city. It was coinciding with the anomaly high tide that made sea level is higher than in normal period. By this time people started to realize about risk from global climate change, everybody started to talk more about sea level rise and tidal inundation (In Javanese they call it "Rob"). Base on the research using satellite altimetry it revealed sea level rise around sea of Jakarta and Semarang for about 6 millimetres per year.

First initiated by Jakarta Coastal Defence Study (JCDS), the scenario of "Giant Sea Wall" is establishing along coastal of Jakarta city. The city would be closed from the sea by more than six meter high of the giant wall located few kilometres from the sea shore. This giant wall will equipped by pumping station and inner lake as retention area. JCDS was transformed into NCICD (National Capital Integrated Coastal Development). Formed by The Central Government this NCICD will be executing the Giant Sea Wall Project. A shape of "Great Garuda" on the giant liveable dyke will be created along coastal area of Jakarta. Around 600 trillion rupiah will be spent through scheme Public Private Partnership (PPP). Infrastructures such as highway, railway including airport will be develop on the dyke. Central of business and housing will be part of this liveable dyke as well.
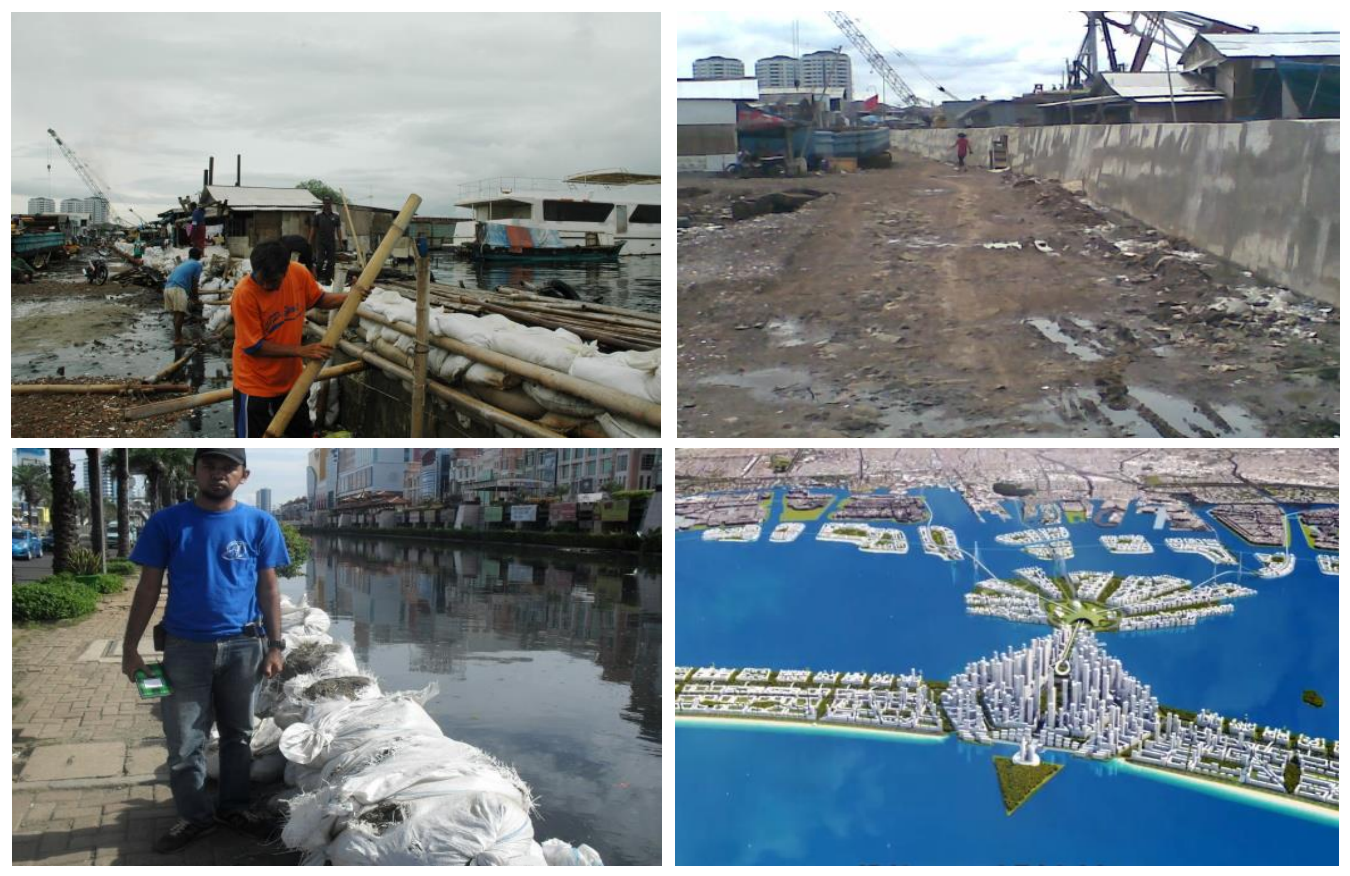

Fig. 7. Adaptation have been created against the slow disaster of sea inundation and abrasion from climate change impact and others influence factors such as build temporary dyke of sand bag, concrete dyke, and also the scenario of "Giant Sea Wall" (Image courtesy NCICD).

Even the dyke is mostly successfully protect the coastal land from sea inundation in quite some time, but there are times of leaked on the dyke, and even broken down, flooded suddenly the area surrounding. It is also surprisingly the sea water can be overtopping. If we calculate the sea level rise or high tide anomaly, this overtopping is beyond expectation, respectively. In this case the dyke is proven to be sinking trough times with rates may reach 10-20 centimetres per year. We found dyke in Jakarta have already increased 1 meter in every five to ten years, and today it is already the third time. So, adaptation on 'early climate change disaster' by using dyke turn out has its own challenge. The scenario of "Giant sea Wall" above maybe it will not be a very best adaptation after all. We perhaps need a combination one and each other of the adaptation's strategies.

People increased their houses while Government increased the road and any public facilities in order to avoid tidal inundation. Surprisingly people have to increase their houses in every five to ten year with at least 1 meter elevated, and we found some people have already been elevate their houses for three times. They used their own money and they said they feel of buying new houses every five or ten year repeatedly. Figure 
8 shows elevated house side by side with the one which is not being elevated. In contrast we can see more then 1 meter different in elevation. Government also elevate the road for several times and huge amount of rupiah have to be spent repeatedly. The break water and also sea dyke have been built to reduce abrasion in coastal area. On Fig. 8, we can also seen unique scenery where house 'privately' located at the sea because surrounding it now permanently inundated and become the sea.

Unique adaptation is also exists by creating net on the fish pond to avoid lost of fish due to upcoming tidal inundation (Fig. 9). Growing mangrove is also another program to protect the coastal from tidal inundation and abrasion. We found the program implemented in Blanakan area, Indramayu, Pekalongan, Semarang and Demak. The concept is to catch sediment that would become a barrier for tidal flooding the land. Nevertheless if the coastal area is sinking along with mangrove tress, in this case the tidal would easily flooding the coastal area with or without the existence of mangrove. Perhaps if subsidence is less enough then the sedimentation may become barrier for tidal inundation.
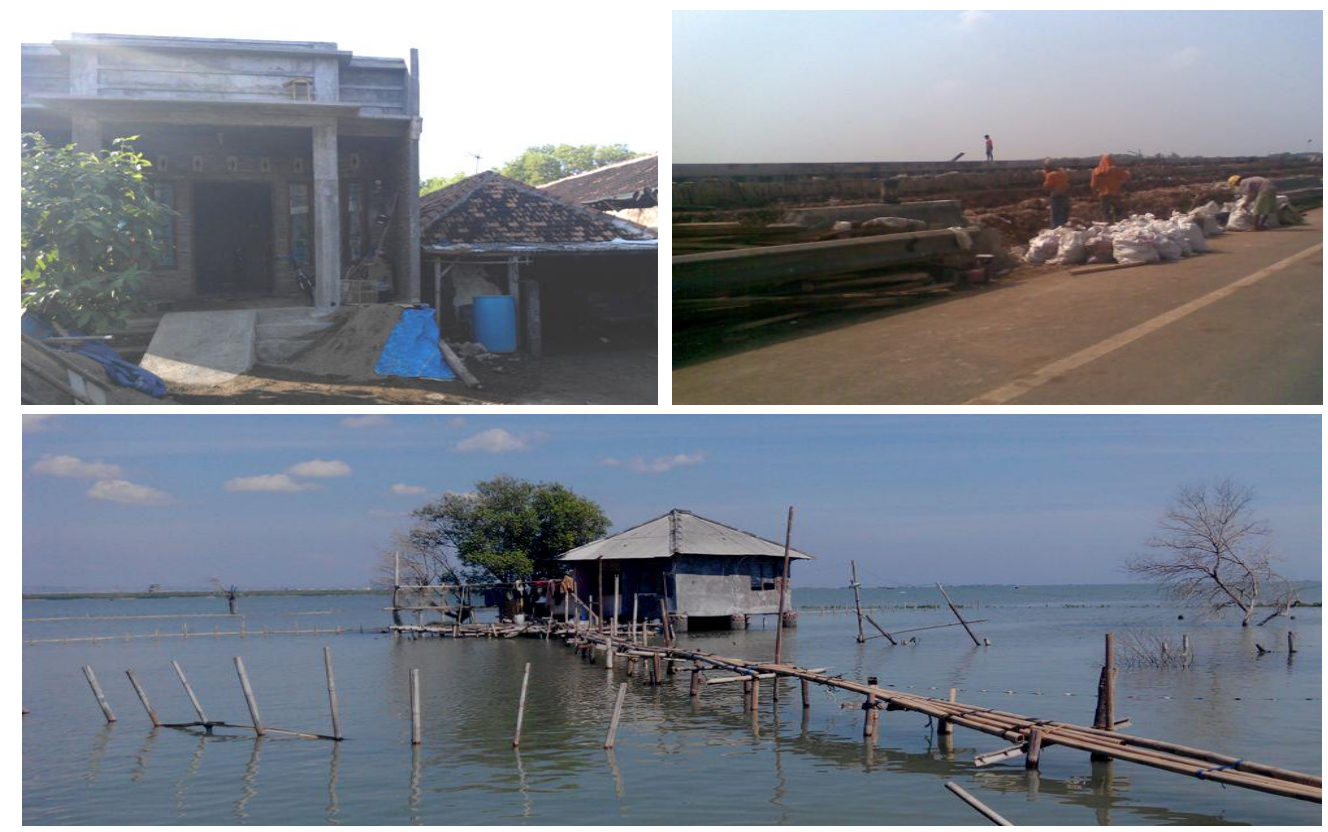

Fig. 8. Adaptation have been created against the slow disaster of sea inundation from climate change impact and others influence factors by increased the houses, elevated the road, and survived the house like "a private place" at the sea.
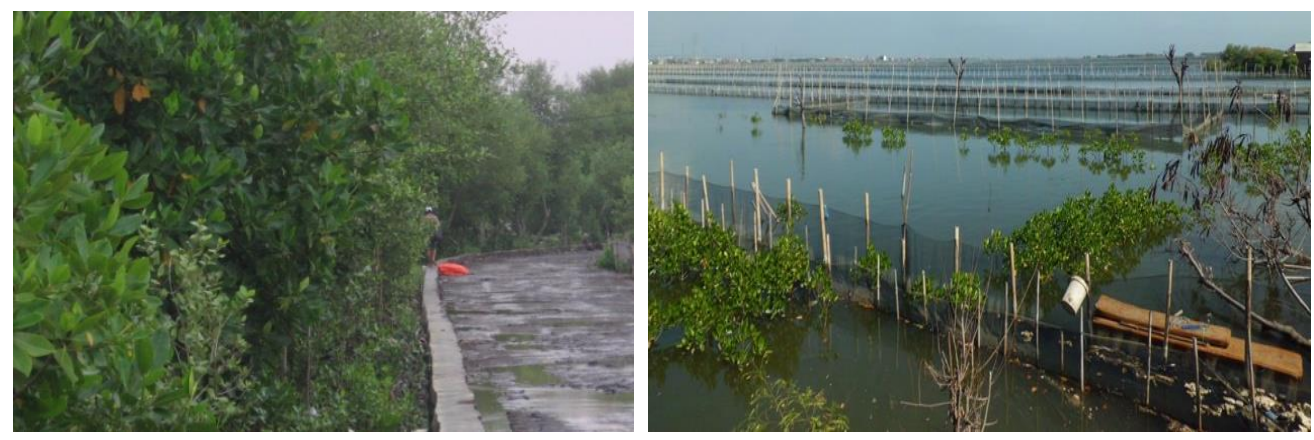

Fig. 9. Adaptation have been created against the slow disaster of sea inundation and abrasion from climate change impact and others influence factors by growing the mangrove, and an unique way of creating the net on fish pond area.

Another unique adaptation is also exists which is raised the grave yard to avoid tidal inundation. For the one which is un-raised it is literally drowning below the water through times. Indeed it looks tragic when dead people still have to 'suffer' from the disaster. It is also would leave the sadness to the family living when they found their family grave yard gone below the water. The Government should think very serious about this 
situation and take appropriate actions. The graveyard affairs in Indonesia are under Government responsibility. We have found these situations at Tegal, Pekalongan, Semarang, and Demak areas. It is probably we would found more in somewhere else un-surveyed. If we may make a statement this situation is one of most tragic situation from 'early global climate change disaster'.
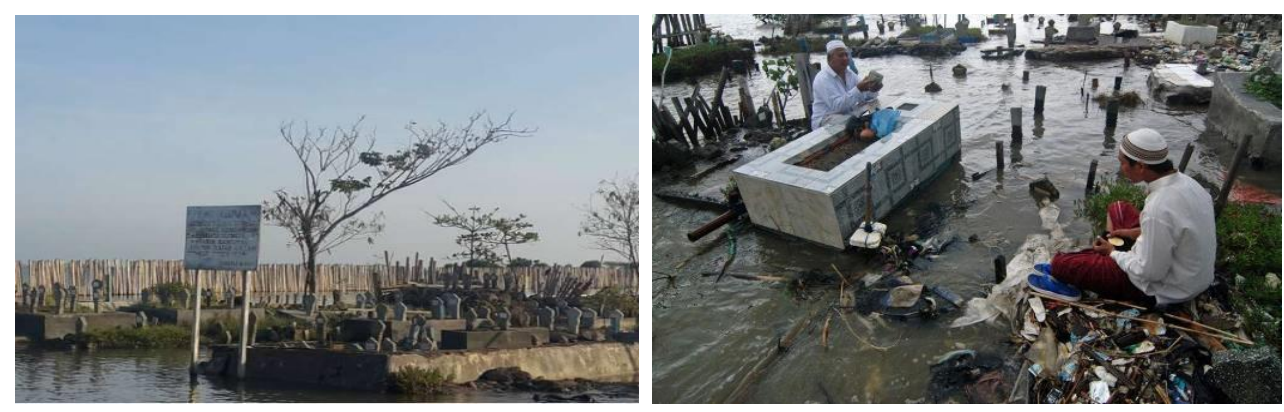

Fig. 10. Unique adaptation of increased the grave yard has been implemented against the slow disaster of sea inundation from climate change impact and others influence factors.

Figure 11 shows map summary that picturing spatially the adaptation of tidal inundation and abrasion disaster to the northern coast of Java Indonesia. We can see the adaptions are taking place in nearly all area along the coast. At least there are six cities and 101 villages who are busy in adapting the disaster. What is happening to this area is one most clear pictures of 'early climate change' disaster. As mentioned in the beginning this is one way to remain on what would happen in the future world wide as the global climate change consequences are finally coming. We realize by the news the projection model of sinking coastal city in the world, vanishing Islands around the Pacific, etc. in the future.
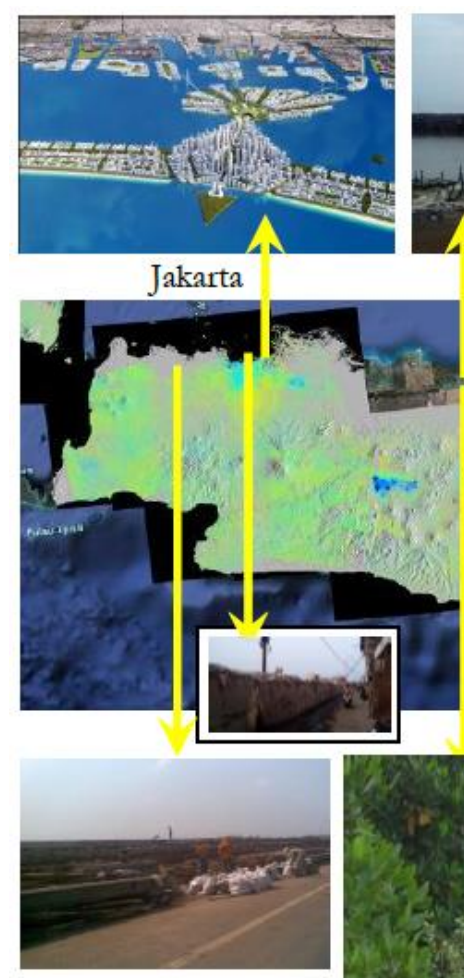

Tanggerang
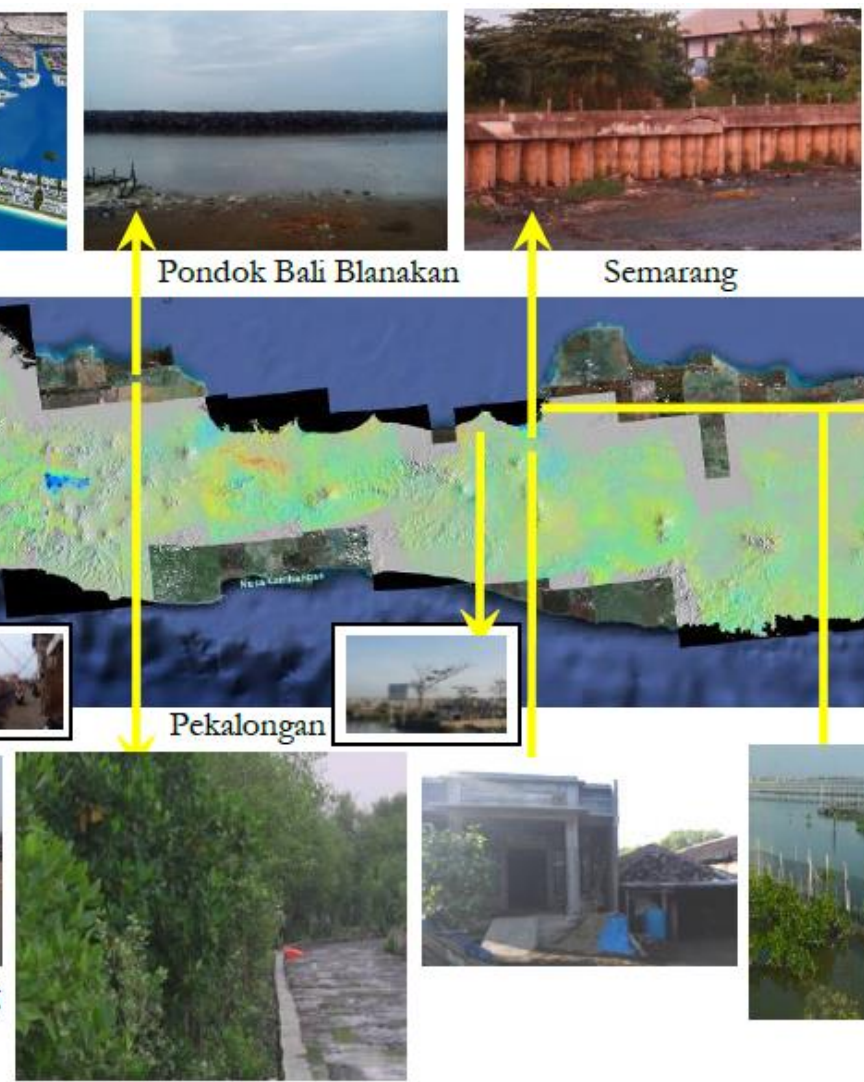

Pondok Bali Blanakan
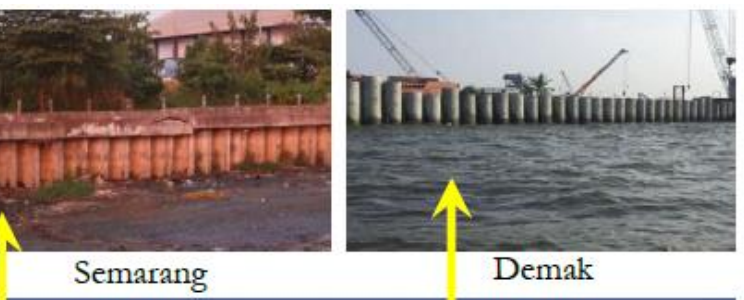

Demak
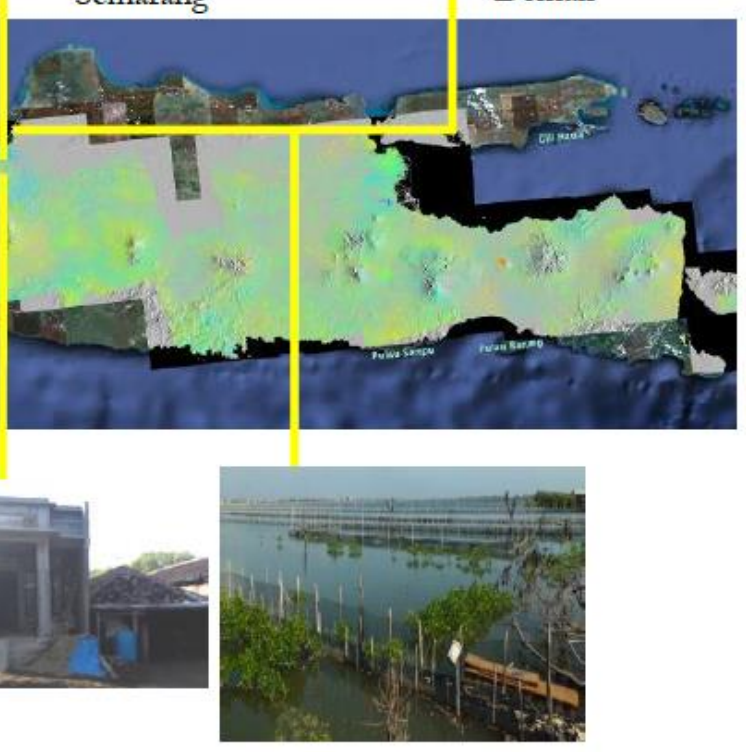

Fig. 11. Map summary spatially of tidal inundation and abrasion documentations in many locations along northern coast of Java Island Indonesia. 


\section{Closing Remarks}

As mentioned in the introduction, humans have caused major global climate changes today. Most climate scientists agree the main cause of the global climate changes is further effect of current global warming trend by human expansion of the "greenhouse effect". Certain gases like CO2 in the atmosphere block heat from escaping. Humans have increased atmospheric $\mathrm{CO}_{2}$ concentration by more than a third since the Industrial Revolution began. This is the most important long-lived "forcing" of global climate change. This global climate change situation due to global warming has been realized for the few decades. Some indicators are worldwide increasing temperature, decreasing volume of ice in Antarctica, the sea level rise, and not to mention the severe storm surge and any of bad weathers anomaly. Generally the sea level rise is ranging in order millimetre to few centimetres per year.

The sea level rise has been predicted to endanger the living at the coastal area in the future. Prediction models have shown some coastal cities area would suffer flood by tidal inundation and even permanent flooding. The tidal inundation in certain form may lead to serious ecological disaster. People may suffered from the inundation (e.g. health, economic, and even social), and some probably even have to evacuate from their homeland. Environments are degrading in their quality as well. Severe storm surge and any of bad weathers anomalies would come more frequently due to another consequence of global climate change. When they strike the coastal area, potential abrasion increase and in certain time formed disaster to the area. Both the sea level rise and grown abrasion, they will be a disaster

In the last few decades, the flood of tidal inundation and abrasion along northern coast of Java Indonesia has been grown very rapidly. These situations are far beyond the geological scale. These are way too fast. Many of urban and other areas like farming area, fishpond, etc. have been suffered tidal inundation and abrasion. What is happening to the northern coast of Java Island Indonesia is one most clear pictures of 'early climate change' disaster. Adaptation has been created against this disaster situation such as build dykes, elevate the land, houses, infrastructures, etc. One or even two meter of dyke already can be seen in several places along the coastal area. A huge plan on establishing permanent dyke is prepared in Jakarta and Semarang city. There will be "Giant Sea Wall" closing Jakarta Bay, and Toll Dykes along shoreline of Semarang in the near future. People increased their houses while Government increased the road and any public facilities in order to avoid tidal inundation. The break water and also sea dyke have been built to reduce abrasion in coastal area. Growing mangrove is also another program to protect the coastal from tidal inundation and abrasion. Unique adaptation are also exists like raised the grave yard to avoid tidal inundation, and creating net on the fish pond to avoid lost of fish due to upcoming tidal inundation.

If we take a closer look, we would realize that none of adaptation involved directly the sources of disaster. If the sea level rise and the abrasion are continuing with the same characteristic or even changing worse, and we have subsidence as other crucial source, as the consequences the disaster may keep coming. Even if we built the Giant Sea Wall "Great Garuda" it won't guaranty that the sea wall is long last protecting the land if it is subsiding and sea level finally higher than the wall. So, along with ongoing adaptation, we need to understand also how to stop or at least reduce the sea level rise, the subsidence, and the abrasion. Understanding the forces derived tidal inundation, subsidence and abrasion, from climatology, geological and hydro geological perspective is a key that can make better way in adaptation or mitigation. Perhaps the forces can be controlled or even demolish naturally, soon if we truly understand them.

Fortunately stopping ground water, oil and gas abstraction can reduce or even stop the land subsidence. There are few example of successfully stop the land subsidence (Teatini, 2014; JICA, 2014). Meanwhile dealing with the sea level rise is still beyond our capability since it is involving many parameters in a global scale like "green house effect global warming". Maybe reducing sources of $\mathrm{CO} 2$ for reducing global warming (for example, the burning of fossil fuels for electricity, heat or transport) or enhancing the "sinks" that accumulate and store these gases (such as the oceans, forests and soil) is not easy so far. We need world scale complex policy.

As for the case of northern coast of Java, hypothesis very convince said that the sea level rise and the land subsidence are major driving forces for the occurring of tidal inundation phenomenon. It means that land subsidence is most probably taking places in many places along the northern coast of Java. Indeed according to publication (e.g. Murdohardono and Tirtomihardjo 1993; Murdohardono and Sudarsono 1998; Rajiyowiryono 1999; Abidin et al. 2001, 2004, 2005, 2008a, 2010a, 2011; Koudogbo et al., 2012; Ng, A.H.-M et al., 2012; Chaussard et al., 2013) the land subsidence is happening around northern coast of Java Island such as in Jakarta, Pondok Bali Blanakan, Pekalongan, Semarang and Demak. The evidence for subsidence was based on repeated levelling measurements, GPS surveys, InSAR measurements, extensometer, etc. 
Stopping groundwater, oil and gas exploitation along northern coast of Java may decrease or even stop the subsidence, and in this case it may reduce also the tidal inundation phenomenon. Nevertheless it is still a big homework, not easy to execute. Stopping oil and gas abstraction is even more difficult. Record shows about 64 percent of need of clean water in Jakarta city is fulfilled by groundwater abstraction because Public Utilities provide only $\sim 35$ percent of the population with it, and only $\sim 2$ percent of industrial needs. This situation is assumed generally the same in many places along northern coast of Java, especially in the big cities. Not to mention the northern coast of Java is one of the strategic places for our national development where urban development will be huge in the future and the need of water is also huge, in this case stopping groundwater along northern coast of Java is even harder to execute.

More surprisingly even the Government both Local and Central, and among experts are still arguing about this tidal inundation induced by land subsidence and sea level rise phenomenon. Some believes the tidal inundation is only caused by sea level rise as consequences from global climate change, while some believes it is caused by combination of land subsidence and the sea level rise. Further on, the causes of land subsidence are also still under argumentation among experts and the policy maker. Some people believes that the subsidence is caused by ground water extraction, oil and gas extraction, and we can reduce or stop it by stopping groundwater, oil and gas extraction. Nevertheless some even confidently said the land subsidence is caused by tectonic which is we cannot do something about it.

\section{References}

[1] IPCC: Climate Change 2013: The Physical Science Basis. Contribution of Working Group I to the Fifth Assessment Report of the Intergovernmental Panel on Climate Change, T. F. Stocker, D. Qin, G.-K. Plattner, M. Tignor, S. K. Allen, J. Boschung, A. Nauels, Y. Xia, V. Bex, and P. M. Midgley, Eds. Cambridge, United Kingdom and New York, NY, USA: Cambridge University Press, 2013.

[2] S. L. Nurmaulia, L. Fenoglio-Marc, and M. Becker, "Long term sea level change from satellite altimetry and tide gauges in the Indonesian region," presented at the EGU General Assembly 2010, 2-7 May 2010, Vienna, Austria.

[3] M. Budianto Eko, "Regulasi dan kebijakan rehabilitasi kawasan Pesisir," presented at Seminar Nasional Mangrove; Mangrove for the future (MFF), Indonesia, 2012.

[4] P. Ruhdi and M. Helmi, "Pemetaan status kerusakan wilayah pesisir Pantura Jawa: Studi kasus di Jawa Tengah," presented at Seminar Nasional Mangrove; Mangrove for the future (MFF), Indonesia, 2012.

[5] NCICD, Project Report, 2014.

[6] Teatini, "Lesson learned from land subsidence in Venice, Italy. Presentation on 'high level meeting on subsidence,", Balai Kota DKI, Jakarta, Indonesia, 2014.

[7] JICA, (2014). "Lesson learned from land subsidence in Tokyo Japan. Presentation on "high level meeting on subsidence'," Balai Kota DKI, Jakarta, Indonesia, 2014.

[8] D. Murdohardono and H. Tirtomihardjo, "Penurunan tananh di Jakarta dan rencana pemantauannya," in Proceedings of the 22nd annual convention of the Indonesian Association of Geologists, Bandung, 6-9 December 1993, pp. 346-354.

[9] D. Murdohardono and U. Sudarsono, "Land subsidence monitoring system in Jakarta," in Proceedings of symposium on Japan-Indonesia IDNDR Project: Volcanology, Tectonics, Flood and Sediment Hazards, Bandung, 21-23 September 1998, pp. 243-256.

[10] H. Rajiyowiryono, "Groundwater and land subsidence monitoring along the north coastal plain of Java Island," CCOP Newsl., vol. 24, no. 3, p. 19, Jul.-Sept. 1999.

[11] H. Z. Abidin, R. Djaja, D. Darmawan, S. Hadi, A. Akbar, H. Rajiyowiryono, Y. Sudibyo, I. Meilano, M. A. Kusuma, J. Kahar, and C. Subarya, "Land subsidence of Jakarta (Indonesia) and its geodetic-based monitoring system," J. Int. Soc. Prevention Mitigation Nat. Hazards, vol. 23, no. 2/3, pp. 365-387, 2001.

[12] H. Z. Abidin, R. Djaja, H. Andreas, M. Gamal, K. Hirose, and Y. Maruyama, "Capabilities and constraints of geodetic techniques for monitoring land subsidence in the urban areas of Indonesia," Geomat Res, vol. 81, pp. 45-58, 2004.

[13] H. Z. Abidin, "Suitability of levelling, GPS and INSAR for monitoring land subsidence in urban areas of Indonesia," GIM Int, vol. 19, no. 7, pp. 12-15, 2005.

[14] H. Z. Abidin, H. Andreas, R. Djaja, D. Darmawa, and M. Gamal, "Land subsidence characteristics of Jakarta between 1997 and 2005, as estimated using GPS surveys," in GPS Solutions. Berlin/Heidelberg: Springer, 2008. doi:10.1007/s10291-007-0061-0 
[15] H. Z. Abidin, H. Andreas, M. Gamal, I. Gumilar, M. Napitupulu, Y. Fukuda, T. Deguchi, Y. Maruyama, and E. Riawan, "Land subsidence characteristics of the Jakarta Basin (Indonesia) and its relation with groundwater extraction and sea level rise, in Groundwater Response to Changing Climate," in $L A H$ Selected Papers on Hydrogeology No. 16, M. Taniguchi and I.P. Holman, Eds. London: CRC Press, 2010, ch. 10, pp. 113-130.

[16] H. Z. Abidin, H. Andreas, I. Gumilar, Y. Fukuda, Y. E. Pohan, and T. Deguchi, "Land subsidence of Jakarta (Indonesia) and its relation with urban development," Nat. Hazards, vol. 59, no. 3, pp. 1753 1771, 2011.

[17] F. N. Koudogbo, J. Duro, A. Arnaud, P. Bally, H. Z. Abidin, and H. Andreas, "Combined X- and Lband PSI analyses for assessment of land subsidence in Jakarta," in Proc. SPIE, Remote Sensing for Agriculture, Ecosystems, and Hydrology XIV , International Society for Optics and Photonics, 2012, vol. 8531, p. 853107. doi:10.1117/12.974821

[18] A. H. M. Ng, L. Ge, X. Li, H. Z. Abidin, H. Andreas, and K. Zhang, "Mapping land subsidence in Jakarta, Indonesia using persistent scatterer interferometry (PSI) technique with ALOS PALSAR," Int. J. Appl. Earth Observ. Geoinf., vol. 18, pp. 232-242, 2012.

[19] E. Chaussard, F. Amelung, H. Z. Abidin, and S. H. Hong, "Sinking cities in Indonesia: ALOS PALSAR detects rapid subsidence due to groundwater and gas extraction," Remote Sensing of Environment, vol. 128, pp. 150 -161, 2013. Available: http://dx.doi.org/10.1016/j.rse.2012.10.015 